\title{
Becoming a Caterpillar: \\ A Multimodal Perspective \\ on Metamorphosis in Butoh
}

\section{Dance}

VIDEO ARTICLE

PAOLA ESPOSITO (1)

\section{DARIUSZ DZIALA}

*Author affiliations can be found in the back matter of this article

\section{ABSTRACT}

Butoh is a dance and somatic movement approach that emerged in Japan in the 1960s and today is practiced around the world. Due to its stylistic idiosyncrasies and lack of a formalised movement vocabulary, butoh is often referred to among its practitioners and in the literature as an indeterminate or 'formless' dance. While 'metamorphosis' has been recognised as butoh's core aesthetic trait (Fraleigh 2010; Baird and Candelario 2019), what this entails in practice has been little explored.

This video article examines metamorphosis in butoh dance from a sensory anthropology perspective which attends to the micro-phenomenological dimensions of the practice. The author, a dancer-anthropologist, focuses on a practice of 'becoming a caterpillar' that she learnt at a butoh workshop given by Semimaru of the company Sankai Juku in London in 2014. Through a praxeography of selected exercises, integrated by a somatic or 'from the body' perspective (Farnell 1999), the author argues that the same techniques 'scaffold' (Downey 2004) metamorphosis by emphasising fluidity of bodily movement as well as the 'isolation' of body parts. Perceptual aspects of the practice are explored and reflected upon multimodally through a combination of textual, graphic, dance, and performance reenactments. Responding to ongoing debates on the value of integrating multimodality in anthropological research, practice and dissemination of scholarship, the article proposes that multimodality can extend the conceptual and methodological reach into experiential dimensions of bodily practice by foregrounding both sensory and imaginal aspects of doing. Drawing on anthropological studies of perception in ritual action, the video article argues that butoh metamorphosis relies on a principle of 'illusion' whereby a change in the dancer's kinetic organisation engenders a visual impression of their bodies transforming into something else. This metamorphic logic is by no means exclusive to butoh but is found in other styles of performance, including puppet theatre. Kapferer's (2004) notion of virtuality is mobilised here to highlight how the reconfiguring of perceptual patterns through performative action can effect transformation by means of 'modulating reality' and 'adjusting its dynamics'.

As shown by the example of the caterpillar, in butoh dance the transformation is double: on the optical and imaginal level of the dancer's bodily form, as coinciding with a 'view from the outside', and on the somatic level of the practitioner's lived body as experienced 'from the inside'. It is further argued that a butoh dancer's propension to somatically relate to imaginal dimensions of the practice relies on the phenomenological principle of sensory reversibility, whereby tactility-kinaesthesia 'merges' with the sense of vision.
Open Library of Humanities

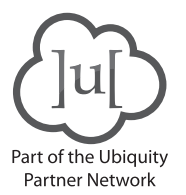

CORRESPONDING AUTHOR:

\section{Paola Esposito}

University of Oxford, GB

paola.esposito@anthro.ox.ac.uk

\section{KEYWORDS:}

Butoh dance; metamorphosis; kinaesthesia; somatic movement; multimodality; graphic anthropology; praxeography; sensory anthropology

TO CITE THIS ARTICLE: Esposito, P and Dziala, D. 2021. Becoming a Caterpillar: A Multimodal Perspective on Metamorphosis in Butoh Dance. Journal of Embodied Research, 4(1): 4 (25:04). DOI: https://doi.org/10.16995/jer.18 
VIDEO ARTICLE

Available to view here: https://doi.org/10.16995/jer.18.

Available for download here: https://doi.org/10.16995/jer.18.s1.

\section{STILLS FROM THE VIDEO ARTICLE}
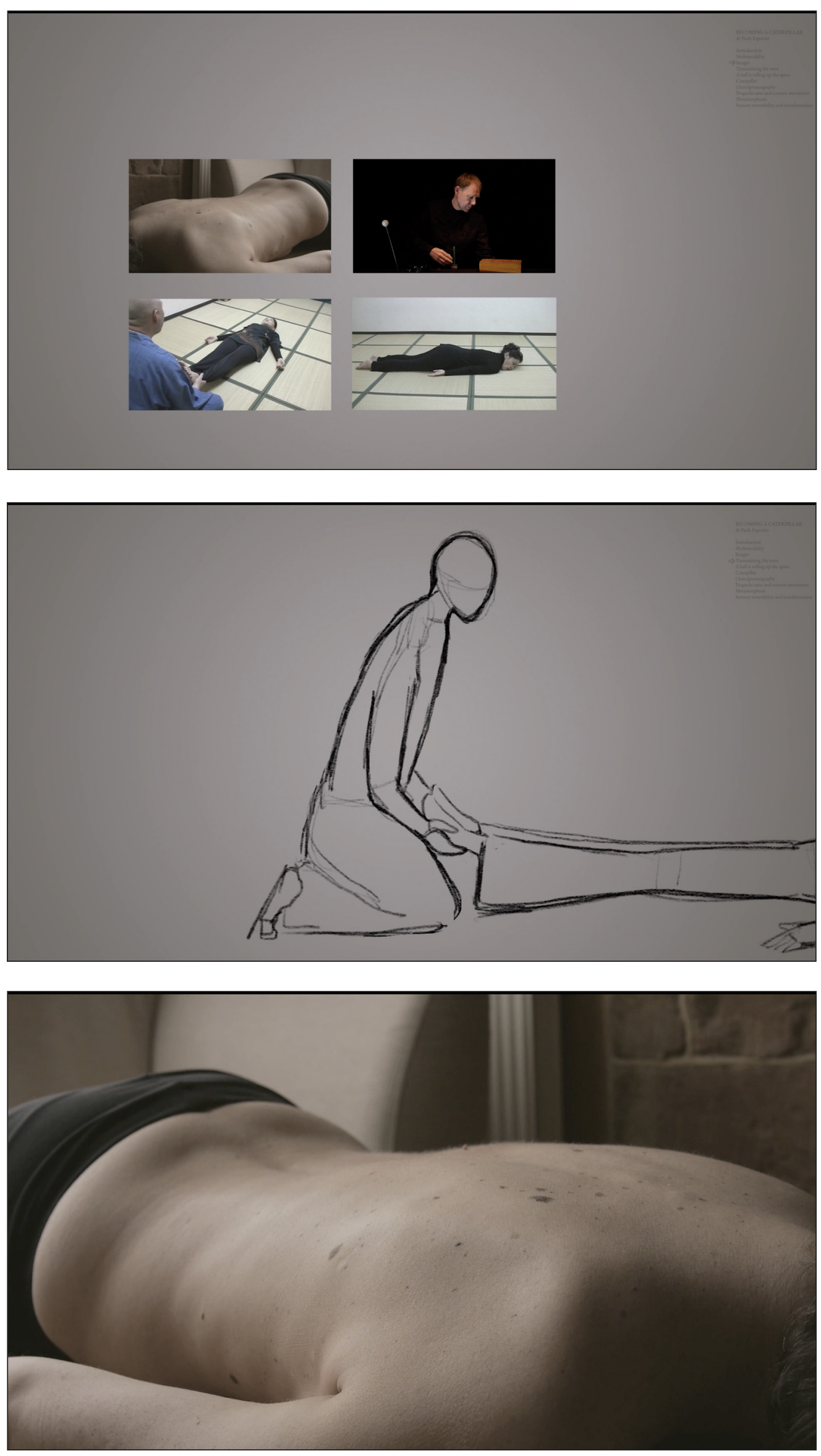


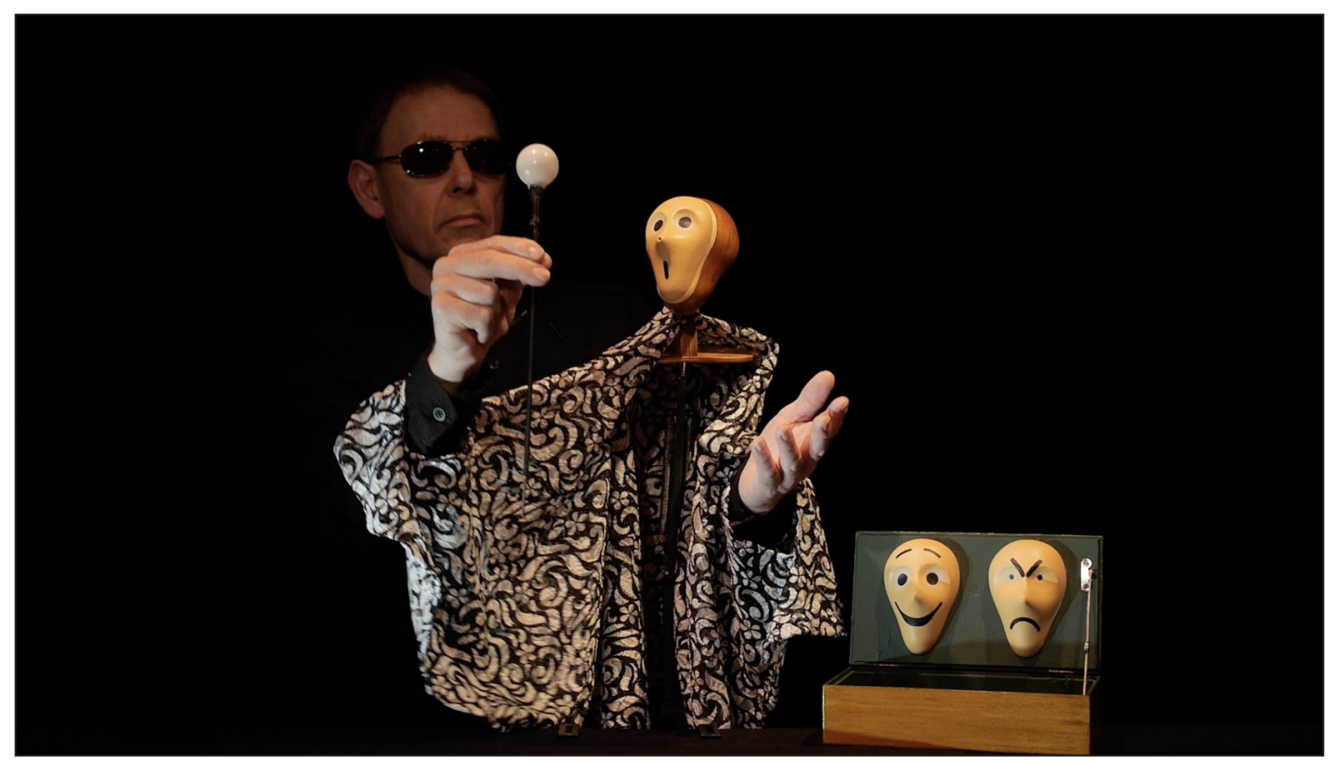

\section{VIDEO ARTICLE TRANSCRIPT}

[Note: This is a transcript of a video article. Individual elements from the transcript, such as metadata and reference lists, may appear more than once in the document, in order to be properly read and accessed by automated systems. The transcript can be used as a placeholder or reference when it is not possible to embed the actual video, which can be found by following the DOI.]

[00:10]

\section{Becoming a Caterpillar:}

A multimodal perspective on metamorphosis in butoh dance

Paola Esposito and Dariusz Dziala

[00:20]

\section{Contents:}

$\begin{array}{ll}\text { Introduction } & 00: 26 \\ \text { Multimodality } & 02: 16 \\ \text { Images } & 03: 41 \\ \text { Transmitting the wave } & 06: 30 \\ \text { A ball is rolling up the spine } & 08: 27 \\ \text { Caterpillar } & 09: 34 \\ \text { (Auto)praxeography } & 10: 45 \\ \text { Noguchi taiso and somatic movement } & 14: 31 \\ \text { Metamorphosis } & 15: 48 \\ \text { Sensory reversibility and transformation } & 19: 27 \\ & \\ \text { Dr Paola Esposito } & \\ \text { University of Oxford } & \end{array}$

Butoh is a dance form that emerged in Japan in the 1960s. It is said to be formless because it does not rely on any particular form or style of movement. Instead, butoh's most distinctive trait is said to be metamorphosis. Butoh practitioners become plant-, animal- or element- like. They can also become spirit- or ghost- like. Their movements can be improvised or choreographed, or a combination of both. What does metamorphosis mean in practice?

metamorphosis 
This research video explores a particular instance of metamorphosis in butoh, that of becoming a caterpillar. As an anthropologist and butoh practitioner, I first encountered the caterpillar exercise at a butoh workshop at the London Laban studios in 2014. The workshop was given by a member of the company Sankai Juku, Semimaru. On day one, in the first half of the class, Semimaru introduced us to a set of exercises, primarily engaging the movement of the spine. All those exercises provided the groundwork for the caterpillar movement. For the purpose of this video, I will focus on the last two of those exercises: they are 'transmitting the wave' and 'a ball is rolling up the spine.'

Transmitting the wave

A ball is rolling up the spine

Following the practice, Semimaru himself demonstrated the caterpillar movement. In a few instants he crawled from one side to the other of the dance studio, with a swiftness that could only be compared to that of an actual caterpillar.

This video cannot replicate the magic of those few instants. What this video does is to explore the perceptual dynamics 'scaffolding' (Downey 2008) the transformation through a combination of textual, graphic, movement and performance 'reenactments' (MacDougall 2006).

\section{[02:16]}

\section{Multimodality}

This video responds to ongoing debates on the value of integrating multimodality in anthropological research, practice and dissemination of scholarship (Collins et al 2017; Cartwright and Crowder 2017; Nolas and Varvantakis 2018; Canals 2018). It focuses on whether multimodality can further a sensory anthropology approach (Pink 2011) to the study of embodied practices.

While this research video is based on a masterclass with the company Sankai Juku, it is not about Sankai Juku, nor is it a document of their work. This video's aim is not to teach butoh, or a specific butoh technique. It is rather to engage multimodally with a particular way of 'thinking in movement' (Sheets-Johnstone 1981; 1999), as represented here by the practice of 'becoming a caterpillar' in particular, and of butoh metamorphosis in general.

The training thus is a pretext to think about how a particular way of working with the body can become an art of inquiry (Ingold 2013) in its own right. Here, a particular style of somatic movement practice (Hanna 1988; Nicely 2018) becomes a strategy for thinking 'with' (Ingold 2013) as well as 'from' (Farnell 1999) the body.

While the analysis adopts a phenomenological focus on the micro-dynamics (Petitmengin et al. 2019) of the exercises, the overall approach can be seen as both autoethnographic and praxeographic.

By re-enacting the process of learning a technique of the body, the anthropologist-cum-butoh dancer observes how the body is 'being done' (Mol 2002: 32), is 'crafted' (Harris 2016), or, 'surfaces' (Taylor 2005) through that practice.

[03:41]

\section{Images}

The images used in this video were filmed in different places and with different people, with different video 'registers' emphasising different aspects of the practice.

The solo and partner videos by Morita and Takeuchi offer a literal reenactment of the practice. They isolate the practice from its ethnographic context, in order to zoom in on the techniques.

The solo dance video with Ana Barbour is a more aesthetic interpretation of the exercises. It uses haptic cinema techniques (Marks 2000) to hint at tactilekinaesthetic dimensions of the practice. 
The video with Stephen Mottram mobilizes the aesthetics of puppet theatre to make a core theoretical point on the relationship between sensory perception and metamorphosis.

Finally, animations reenact kinaesthetic experiences in graphic form.

MacDougall (2006) saw images as artifacts of modes of perceiving attentively, not only by using one's eyes but one's whole being. He saw images as 'mirrors of our bodies, replicating the whole of the body's activity, with its physical movements, its shifting attention, and its conflicting impulses toward order and disorder' (MacDougall 2006: 3).

While most of the images in this video enact a 'mirroring' perspective that does not transgress the boundary of the skin even as they point to internal processes, graphic methods enact a somatic, first-person perspective on doing butoh (Hanna 1988; Farnell 1999).

As anthropologist Michael Taussig (2009) points out, drawing establishes an organic bond with what it's being depicted. Used as a phenomenological device, a drawing hand can attune to the inner spaces of the body, opening ways of inquiry and communication. Drawing in this sense is not a representational strategy but a 'reenactment' (MacDougall 2006: 272) of experiential dynamics.

Some of the materials used in this video are 'provisional' such as my fieldwork notes and sketches. This is in line with a multimodal approach, which highlights the personal and intellectual process that lies at the base [sic] of anthropological research' and the fact that fieldwork 'like any lived experience ... [is] a nonlinear, dialogical, and fragmentary path.' (Canals 2017: 126).

Here, montage is used not just to point to the invisible (Suhr and Willerslev 2013), but provocatively, also to make the invisible visible.

The next sections engage multimodally with the practice of becoming a caterpillar by drawing on sensory anthropological perspectives on perception in ritual action. More information about this project and its contributors can be found in the end credits.

[06:27]

\section{Praxeography of butoh training}

\section{Transmitting the wave}

Semimaru invites his assistant to lay down, face up, and help him demonstrate 'transmitting the wave'. He then kneels down at the assistant's feet, and grabs his ankles. Semimaru explains that his own body is strong and relaxed as he lifts his assistant's feet few inches off the ground. Next, he shakes his assistant's feet, creating tiny waves that travel through the assistant's body. The source of these perturbations is Semimaru's hara which is located few inches below the navel and is considered the centre of the body in Japanese culture.

A similar technique which initiates undulatory movements in the body through the ankles towards the pelvis, chest and head is a Noguchi taiso technique called nenyoro (Morita, personal conversation). In this video, Itto Morita and Mika Takeuchi demonstrate nenyoro. Morita describes nenyoro as following:

Lie down on the floor on your back. Stretch your knees.

Your partner catches both your ankles, and holding them together, shakes your legs to the left and right briskly, making your entire body wave.

Check if the head is swaying to some extent as a result of this waving

Your partner changes the shaking speed and the amplitude so as to make an irregular movement in the body.

(Esposito and Kasai 2017: 260).

The Japanese name of this exercise, Nenyoro is composed of two words, ne, meaning 'lying' and nyoro a mimetic word describing a 'snaky' movement. (Esposito and Kasai 2017: 260). 
This name offers a cue as for the movement quality that this exercise is meant to produce. Images of a snaky body or water body inform this exercise. When this condition is achieved in nenyoro, the dancer's body will behave as a jelly-like waving matter and will be highly reactive to any movement variations that are applied by the sitting partner.

[08:27]

\section{A ball is rolling up the spine}

Semimaru kneels down by his assistant's side, who is now lying face down. Semimaru gently pushes the assistant's torso side to side, to make sure that is limp and relaxed. He then carefully rolls up the assistant's T-shirt, exposing his back, and places one fingertip on his tailbone. Semimaru says that this is the entry point for a ball, about the size of a marble. This ball is to come in from the tailbone and then travel all the way up the assistant's spine, to come out at the top of the head (Semimaru indicates the exit point at the top of the assistant's head).

When Semimaru touches the point on the tailbone a second time, this prompts the assistant to begin. The dancer's spine unfurls from that very point, as though each and every vertebra were moving independently, raising up before flattening down again in a rippling motion. From a viewer's perspective, the impression is of a tiny ball rolling under the skin all the way up the spine.

[09:34]

\section{Caterpillar}

After the demonstration, Semimaru himself shows the complete version of the exercise with the ball. That is, Semimaru uses the same technique to travel across the space in a continuous waving motion. This is the caterpillar. After the demonstration, Semimaru recalls the times when he and his friends, as young Sankai Juku dancers, used to compete in 'caterpillar races'. The image of a racing caterpillar, in stark contrast with the teacher's monastic demeanour, triggers a wave of chuckles in the room.

In this video Mika Takeuchi demonstrates the caterpillar movement.

$[10: 45]$

\section{(Auto)praxeography of butoh training}

\section{A ball is rolling up the spine}

(a somatic perspective on learning the caterpillar movement)

In this section I discuss the exercise 'a ball is rolling up the spine' from a somatic or 'from the body' perspective (Farnell 1999), as based on my own notes from the practice.

I am lying face down. My dance partner Flavia is sitting next to me. To begin with, she pushes my torso side to side, to make sure that is limp and relaxed. She then waits until it gradually returns to stillness.

I sense my body responding to the induced movement by progressively giving in to gravity. As kinetic energy ripples across my body, I begin to differentiate the shapes and weights of different body parts.

A deepening of my breathing further enhances letting go and relaxation. The ripple-like movements initiate a change in the body.

They awaken my proprioceptive sense of bodily weight and bring to the fore my body's relationship with gravity. This relationship is not homogeneous however. The ripple-like movements highlight my body's heterogeneity, its different shapes and weights spread out on the floor. The relationship with gravity is also heterogeneous and diffuse. 
I sense my skin receiving a subtle touch - my partner's fingertip - sitting on my tailbone first, then at the top of my head. I recognise these touches as the 'entry' and 'exit' points respectively for the ball and, implicitly, as a prompt to begin.

It takes me a few seconds to resurface from the state of deep relaxation and stillness.

The contrast between a resistance to move and the expectation of having to engage in the practice creates a perceived distance between my 'intention to move' and my body as a quasi-inert 'thing'. My body turns into an unfamiliar, unexplored territory.

My attention hovers as though from above my body, looking for trails of action. I return to the lingering sensation of my partner's touch on my tailbone. This sensation begins to overlap with the image of the ball 'entering' through that point. It is as though, the tactile impression left by a fingertip onto my skin gradually morphed into the 'virtual object' (Gibson 1979) of the ball.

That is, a tactile perception and the image of the marble merge in my mind's eye into a single tactile-kinaesthetic image.

It then occurs to me that the marble is not supposed to sit on the tailbone but should roll up the spine. This image triggers the following micro-actions.

My tailbone flexes upward then downward, leading the small of the back to arch downward and upward respectively. With the first micro-action, the imaginary ball enters the spine, while with the second it rolls up the lumbar spine.

At this point, I find that to maintain the momentum which would allow the ball to cross the lumbar depression, my front abdominal muscles ought to firmly press against the floor. Yet, instead of climbing up the middle of the back as I had intended, the marble sinks under the skin, and I lose track of it.

The middle of the back or thoracic spine is anatomically the least mobile section of the spine. This is where my ball gets stuck and disappears.

It takes a few attempts to perform this movement correctly.

I rely on the tactile and vocal feedback of my partner to fine tune the execution. In order for the 'ball' that is the vertebrae, to become visible, I ought to expand my chest upwardly. I use the diaphragm muscles to lift the corresponding section of the spine.

I cling onto the kinaesthetic image of the ball rolling up the last section of my spine till the top of the head where it comes out.

[14:31]

\section{Noguchi taiso and somatic movement}

The use of the ball as a virtual prop highlights the analytical approach to movement that is required to perform this exercise. However, this anatomical representation does not do justice to the overall perceptual experience of doing the caterpillar.

When we consider the style of proprioceptive and kinaesthetic engagement involved in doing this exercise a more suitable model is offered by Noguchi taiso, a somatic movement approach that has had an important influence on the development of butoh (Baird 2012).

Noguchi taiso posits the body as "a kind of water bag in which our bones and viscera are floating' (Kasai 1999). A somatic attuning to this image involves an attending to proprioceptive dimensions such as the body's relationship with gravity, and the weight of different limbs (Esposito and Kasai 2017); also, to micro-movements understood as felt vibrations, or as micro-waves that can spread easily across the body.

Thus, Noguchi taiso invites fluidity of movement within an overall sense of corporeal heterogeneity. 


\section{Metamorphosis}

While a first-person, somatic approach is key to capturing the micro-phenomenological

(Petitmengin et al. 2019) dimensions of the practice, a more complete account requires the mobilising of a third-person perspective, or view from the outside. This involves turning our attention to imaginal aspects of movement as grounded, in this case, in the sense of vision (Sheets-Johnstone 1999).

As already mentioned, the aesthetic 'efficacy' of the exercise 'a ball is rolling up the spine' lies in the vertebrae becoming visible in a sequential way. This action, when skilfully executed, gives the visual impression of a ball rolling up the dancer's spine. Drawing on anthropological studies of perception in ritual action (Friedson 1996; Kapferer 2004; Willerslev 2007), I refer to this visual effect as an optical 'illusion'. I further argue that optical illusion is at the basis of metamorphosis in butoh as in other performative and ritual contexts.

Despite variations of shape and size, the human form is distinctive. Spinoza ascribed this distinctiveness to the relations of 'motions' which, within and between bodies, support our recognition that a human being is not a chair (Spinoza and Curley 1994: 61; 125; Lord 2010: 61-62) nor any other thing, living or non-living, except for a human being. That is, relations of motion allow one to tell the human from the non-human.

When relations of motions are altered or subverted, then metamorphosis might ensue. Anthropologist Willerslev (2007) explores this dynamic when he describes how Yukaghir hunters are on the verge of 'becoming' their prey, the elk.

By making their bodily movements elk-like, the hunter creates a 'mirror image' of the elk, in an attempt to be perceived by the animal as one of their species.

A related example of metamorphosis based on altered relations of motion comes from puppet theatre.

In this video, puppeteer Stephen Mottram uses a set of lit balls to create the impression of human and other living beings moving about. Mottram's craft is based on research in cognitive psychology on how an audience visually perceive movement from the stage. As a performer his role is to organise the audience's visual perception by providing them with salient movements.

Mottram's work can also be understood through the notion of 'virtuality' as developed by anthropologist Bruce Kapferer's (2004). Working on ritual performance, Kapferer argues that ritual action gains its force in the way sensory perception is dynamically organized to modulate reality. He refers to this process as 'virtuality', which is, an 'imaginal and technical' space 'for entering within life's vital processes and adjusting its dynamics' (48-49).

At the core of Mottram's craft is an understanding of relations of motion, and the way they should be organised to create the illusion of body's aliveness. Butoh dancers do the opposite, the starting point of their dance is to craft the illusion that their bodies are inanimate or quasi-inanimate things (Mottram, workshop with butoh dancers, Oxford 21 March 2015). A dancer's body is to be emptied of the volition that makes us human, so it can be receptive to and animated by relations of motion pertaining to other-than-human beings, like a caterpillar.

[19:27]

\section{Sensory reversibility and transformation}

While I have used the word 'illusion' to describe what happens in the caterpillar exercise, an actual transformation occurs at the level of the mover's perception. Exercises like 'transmitting the wave' or 'the ball is rolling up the spine' lay the groundwork for transformation in three ways.

Firstly, by directing the mover's attention towards nuanced, emergent and induced micromovements, these exercises destabilise habits of gross movement grounded in goal-oriented, agent-centered actions that we enact in daily life. 
Secondly, by enhancing the movement of 'isolated' body parts, these exercises extend the lived body's motility, flexibility and range of expression.

Thirdly, by integrating relations of motion other than those pertaining to a human being, these exercises can alter a mover's 'body image' - in ways that have the potential of being therapeutic.

The difficulty of changing one's body this way should not be underestimated, for the human body is limited in structure and capacity for motion. As an example of the physical and imaginative effort required, consider the following passage from my workshop notes:

'I return to the lingering sensation of my partner's touch on my tailbone. This sensation begins to overlap with the image of the ball "entering" through that point. It is as though the tactile impression left by a fingertip onto my skin gradually morphed into the "virtual object" of the ball.'

The 'translation' of my partner's touch on my skin into a visual image reveals the phenomenological principle of 'reversibility' of, in this case, touch and vision, where a purely tactile impression - my partner's touch on my tailbone - is translated into 'visual language' (Szynkarczuk 2015: 50) - the 'virtual object' (Gibson 1979: 35) of the ball.

These two sensory modalities, the touch and the ball are fused together in my mind's eye into a single kinaesthetic image.

This principle of reversibility, which echoes 'cultural synaesthesia' (Young 2005; Hsu 2021), can be extended to encompass the whole of the dancer's body, as in the caterpillar movement.

Reversibility of tactile-kinaesthetic perception and the language of vision expands both the imagination and the experience of one's corporeal being.

Changing relations of motion involves a change in one's relation with the lived body. It involves a reinhabiting as well as a reimagining of one's body through movement (Hunter et al 2016).

In the case of butoh, this is done primarily through techniques which undermine the habitual sense of one's body as a unified, fixed 'entity', while bringing to the fore its morphogenetic capacity.

Whilst metamorphosis in butoh relies on optical illusion, a transformation actually occurs to the extent that a dancer not only perceives but also sees their body differently. The caterpillar exercise enhances the mobility of the back and changes one's perception of the body. The body is temporarily reconfigured as multiple, just like a caterpillar.

\section{Abstract}

Butoh is a dance and somatic movement approach that emerged in Japan in the 1960s and today is practiced around the world. Due to its stylistic idiosyncrasies and lack of a formalised movement vocabulary, butoh is often referred to among its practitioners and in the literature as an indeterminate or 'formless' dance. While 'metamorphosis' has been recognised as butoh's core aesthetic trait (Fraleigh 2010; Baird and Candelario 2019), what this entails in practice has been little explored.

This video article examines metamorphosis in butoh dance from a sensory anthropology perspective which attends to the micro-phenomenological dimensions of the practice. The author, a dancer-anthropologist, focuses on a practice of 'becoming a caterpillar' that she learnt at a butoh workshop given by Semimaru of the company Sankai Juku in London in 2014. Through a praxeography of selected exercises, integrated by a somatic or 'from the body' perspective (Farnell 1999), the author argues that the same techniques 'scaffold' (Downey 2004) metamorphosis by emphasising fluidity of bodily movement as well as the 'isolation' of body parts. Perceptual aspects of the practice are explored and reflected upon multimodally through a combination of textual, graphic, dance, and performance reenactments. Responding to ongoing debates on the value of integrating multimodality in anthropological research, practice and dissemination of scholarship, the article proposes that multimodality can extend the conceptual and methodological reach into experiential dimensions of bodily practice by foregrounding both sensory and imaginal aspects of doing.

Drawing on anthropological studies of perception in ritual action, the video article argues that butoh metamorphosis relies on a principle of 'illusion' whereby a change in the dancer's 
kinetic organisation engenders a visual impression of their bodies transforming into something else. This metamorphic logic is by no means exclusive to butoh but is found in other styles of performance, including puppet theatre. Kapferer's (2004) notion of virtuality is mobilised here to highlight how the reconfiguring of perceptual patterns through performative action can effect transformation by means of 'modulating reality' and 'adjusting its dynamics'.

As shown by the example of the caterpillar, in butoh dance the transformation is double: on the optical and imaginal level of the dancer's bodily form, as coinciding with a 'view from the outside', and on the somatic level of the practitioner's lived body as experienced 'from the inside'. It is further argued that a butoh dancer's propension to somatically relate to imaginal dimensions of the practice relies on the phenomenological principle of sensory reversibility, whereby tactility-kinaesthesia 'merges' with the sense of vision.

\section{Key words}

Butoh dance, metamorphosis, kinaesthesia, somatic movement, multimodality, graphic anthropology, praxeography, sensory anthropology.

\section{Competing interests}

The authors have no competing interests to declare.

\section{References}

Baird, B., 2012. Hijikata Tatsumi and butoh: dancing in a pool of gray grits. Basingstoke: Palgrave Macmillan. DOI: 10.1353/jjs.2013.0049

Baird, B. and Candelario, R., 2019. The Routledge companion to butoh performance. Abingdon, Oxon; New York, NY: Routledge. DOI: 10.1017/S0307883320000188

Canals, R., 2018. Studying multi-modal religions: migration and mediation in the cult of María Lionza (Venezuela, Barcelona, Internet). Visual Anthropology Review, 34(2), pp.124-135. DOI: 10.1111/var.12169

Collins, S.G., Durington, M. \& Gill, H., 2017. Multimodality: an invitation. American Anthropologist, 119(1), pp.142-146. DOI: 10.1111/aman.12826

Cartwright, E. and Crowder, J.W., 2017. Dissecting images: multimodal medical anthropology. Medical Anthropology, 36(6), pp. 515-518. DOI: 10.1080/01459740.2017.1334058

Downey, G., 2008. Scaffolding imitation in capoeira: physical education and enculturation in an Afro-Brazilian Art. American Anthropologist, vol. 110, no. 2, pp. 204-213. DOI: 10.1111/j.15481433.2008.00026.x

Esposito, P. and Kasai, T., 2017. Butoh dance, Noguchi taiso, and healing. In Karkou, V., Oliver, S. \& Lycouris, S. (eds), The Oxford handbook of dance and wellbeing, New York: Oxford University Press, pp. 255-272. DOI: 10.1093/oxfordhb/9780199949298.013.14

Farnell, B., 1999. Moving bodies, acting selves. Annual Review of Anthropology, 28(1), pp.341-373.

Fraleigh, S.H., 2010. Butoh: metamorphic dance and global alchemy. Urbana: University of Illinois Press.

Friedson, S.M., 1996. Dancing prophets: musical experience in Tumbuka healing. Chicago; London: University of Chicago Press.

Gibson, James J., 1979. The ecological approach to visual perception. Boston, London: Houghton Mifflin.

Hanna, T., 1988. Somatics: reawakening the mind's control of movement, flexibility, and health. Da Capo Press.

Harris, A., 2016. Listening-touch, affect and the crafting of medical bodies through percussion. Body \& Society, 22(1), pp.31-61. DOI: 10.1177/1357034X15604031

Hsu, E., 2021. The healing green, cultural synaesthesia and triangular comparativism. Ethnos, vol. 86, no. 2, pp. 295-308. DOI: 10.1080/00141844.2020.1768137 
Hunter, L., Krimmer, E. \& Lichtenfels, P., 2016. Sentient performativities of embodiment: thinking alongside the human. Lanham.: Lexington Books.

Ingold, T., 2013. Making: anthropology, archaeology, art and architecture. London; New York.

Kapferer, B., 2004. Ritual dynamics and virtual practice: beyond representation and meaning. Social Analysis, 48(2), pp.35-54.

Kasai, T., 1999. A butoh dance method for psychosomatic exploration. Memoirs of the Hokkaido Institute of Technology, No.27 (1999) pp.309-316.

Lord, B., 2010. Spinoza's ethics: an Edinburgh philosophical guide. Edinburgh: Edinburgh University Press.

MacDougall, D., 2006. The corporeal image: film, ethnography, and the senses. Princeton, NJ: Princeton University Press.

Marks, L.U., 2000. The skin of the film: intercultural cinema, embodiment, and the senses. Durham: Duke University Press.

Mol, A., 2002. The body multiple: ontology in medical practice, Durham: Duke University Press.

Nicely, M.V., 2018. Butoh's subversive somatics. Journal Of Dance \& Somatic Practices, 10(1), pp.111-126. DOI: 10.1386/jdsp.10.1.111_1

Nolas, S-M., and Varvantakis, C., 2018. Entanglements that matter. Entanglements: experiments in multimodal ethnography, 1(1):1-4.

Pink, S., 2011. Multimodality, multisensoriality and ethnographic knowing: social semiotics and the phenomenology of perception. Qualitative Research, 11(3), pp. 261-276. DOI: $10.1177 / 1468794111399835$

Petitmengin, C., van Beek, M., Bitbol, M., Nissou, J. and Roepstorff, A., 2019. Studying the experience of meditation through micro-phenomenology. Current opinion in psychology, 28, pp. 54-59. DOI: 10.1016/j.copsyc.2018.10.009

Sheets-Johnstone, M., 1981. Thinking in movement. The Journal of Aesthetics and Art Criticism, 39(4), pp.399-407. DOI: 10.2307/430239

Sheets-Johnstone, M., 1999. The primacy of movement. Amsterdam; Philadelphia: John Benjamins.

Spinoza, B.D. and Curley, E.M., 1994. A Spinoza reader: the Ethics and other works. Princeton; Chichester: Princeton University Press.

Suhr, C. and Willerslev, R., 2013. Transcultural montage. New York: Berghahn Books.

Szynkarczuk, P., 2015. Intercorporeality - Merleau-Ponty's ontology of flesh and butoh dance practice. Doctoral thesis, Goldsmiths, University of London.

Taussig, M., 2009. What do drawings want? Culture, Theory and Critique, 50(2-3), pp. 263-274. DOI: 10.1080/14735780903240299

Taylor, J. S., 2005. Surfacing the body interior. Annual Review of Anthropology, 34, p.741.

Willerslev, R., 2007. Soul hunters: hunting, animism, and personhood among the Siberian Yukaghirs. Berkley, Los Angeles and London: University of California Press. DOI: $10.1525 / 9780520941007$

Young, D., 2005. The smell of green-ness: cultural synaesthesia in the Western Desert (Australia). In R. Bendix and D. Brenneis, eds, The Senses, Etnofoor, vol. 18, pp. 61-77.

\section{Internet sources}

Sankai Juku image, file name: Sankai Juku2.jpg, attribution: CC 2.0 Generic (CC BY 2.0), source: https://commons.wikimedia.org/wiki/File:Sankai_Juku2.jpg

Semimaru (SANKAI JUKU) Workshop Digest (1 August 2020).

蟬丸 (山海塾) ワークショップダイジェスト

https://www.youtube.com/watch?v=RF_P-B65mvs (first accessed September 2020; last accessed July 2021) 
Authors: Paola Esposito and Dariusz Dziala

Performers: Ana Barbour; Itto Morita; Mika Takeuchi; Steven Mottram

Cited practitioners: Sankai Juku; Semimaru

\section{Dance/Movement}

Ana Barbour

Itto Morita

Mika Takeuchi

\section{Puppet Theatre}

Stephen Mottram

\section{Camera, Editing, Motion Design}

Dariusz Dziala

\section{Writing, Graphics, Narration and Direction}

Paola Esposito

\section{Permissions}

This video, released with the agreement of Seminaru, is based on the author's interpretation of Semimaru's work, and should not be taken as a 'final' or 'correct' version of his practice.

Itto Morita and Mika Takeuchi of GooSayTen hold the copyright for all videos featuring them. Permission to use these files was obtained for all formats of the journal.

All performers consented to appear in this video article.

\section{Acknowledgements}

We would like to thank Semimaru for his corrections on a draft version of this video article.

This work would not have been possible without the contribution of Ana Barbour, Itto Morita, Mika Takeuchi and Stephen Mottram. Special thanks to Itto Morita and Mika Takeuchi for the videos of the exercises that they made ad hoc for this project.

Thanks to Peter Loovers and Ricardo Leizaola for their feedback on early versions of this work. We also wish to thank the two anonymous reviewers and the editor of JER for their extended feedback which facilitated the completion of this final version.

This video article is dedicated to the memory of Ana Barbour.

\section{ADDITIONAL FILE}

The additional file for this article can be found as follows:

- Video file. DOI: https://doi.org/10.16995/jer.18.s1

\section{COMPETING INTERESTS}

The authors have no competing interests to declare.

\section{AUTHOR AFFILIATIONS}

Paola Esposito iD orcid.org/0000-0002-6407-3108

University of Oxford, GB

Dariusz Dziala

Independent filmmaker and digital artist

\section{REFERENCES}

Baird, B. 2012. Hijikata Tatsumi and butoh: dancing in a pool of gray grits. Basingstoke: Palgrave Macmillan. DOI: https://doi.org/10.1353/jjs.2013.0049 
Baird, B and Candelario, R. 2019. The Routledge companion to butoh performance. Abingdon, Oxon; New York, NY: Routledge. DOI: https://doi.org/10.1017/S0307883320000188

Canals, R. 2018. Studying multi-modal religions: migration and mediation in the cult of María Lionza (Venezuela, Barcelona, Internet). Visual Anthropology Review, 34(2): 124-135. DOI: https://doi. org/10.1111/var.12169

Cartwright, E and Crowder, JW. 2017. Dissecting images: multimodal medical anthropology. Medical Anthropology, 36(6): 515-518. DOI: https://doi.org/10.1080/01459740.2017.1334058

Collins, SG, Durington, M and Gill, H. 2017. Multimodality: an invitation. American Anthropologist, 119(1): 142-146. DOI: https://doi.org/10.1111/aman.12826

Downey, G. 2008. Scaffolding imitation in capoeira: physical education and enculturation in an Afro-Brazilian Art. American Anthropologist, 110(2): 204-213. DOI: https://doi.org/10.1111/j.15481433.2008.00026.x

Esposito, P and Kasai, T. 2017. Butoh dance, Noguchi taiso, and healing. In: Karkou, V, Oliver, S and Lycouris, S The Oxford handbook of dance and wellbeing. New York: Oxford University Press. pp. 255272. DOI: https://doi.org/10.1093/oxfordhb/9780199949298.013.14

Farnell, B. 1999. Moving bodies, acting selves. Annual Review of Anthropology, 28(1): 341-373. DOI: https://doi.org/10.1146/annurev.anthro.28.1.341

Fraleigh, SH. 2010. Butoh: metamorphic dance and global alchemy. Urbana: University of Illinois Press.

Friedson, SM. 1996. Dancing prophets: musical experience in Tumbuka healing. Chicago; London: University of Chicago Press.

Gibson, James J. 1979. The ecological approach to visual perception. Boston, London: Houghton Mifflin.

Hanna, T. 1988. Somatics: reawakening the mind's control of movement, flexibility, and health. Da Capo Press. Harris, A. 2016. Listening-touch, affect and the crafting of medical bodies through percussion. Body \& Society, 22(1): 31-61. DOI: https://doi.org/10.1177/1357034X15604031

Hsu, E. 2021. The healing green, cultural synaesthesia and triangular comparativism. Ethnos, 86(2): 295308. DOI: https://doi.org/10.1080/00141844.2020.1768137

Hunter, L, Krimmer, E and Lichtenfels, P. 2016. Sentient performativities of embodiment: thinking alongside the human. Lanham: Lexington Books.

Ingold, T. 2013. Making: anthropology, archaeology, art and architecture. London; New York. DOI: https:// doi.org/10.4324/9780203559055

Kapferer, B. 2004. Ritual dynamics and virtual practice: beyond representation and meaning. Social Analysis, 48(2): 35-54. DOI: https://doi.org/10.3167/015597704782352591

Kasai, T. 1999. A butoh dance method for psychosomatic exploration. Memoirs of the Hokkaido Institute of Technology, 27(1999): 309-316.

Lord, B. 2010. Spinoza's ethics: an Edinburgh philosophical guide. Edinburgh: Edinburgh University Press.

MacDougall, D. 2006. The corporeal image: film, ethnography, and the senses. Princeton, NJ: Princeton University Press. DOI: https://doi.org/10.1515/9781400831562

Marks, LU. 2000. The skin of the film: intercultural cinema, embodiment, and the senses. Durham: Duke University Press. DOI: https://doi.org/10.1215/9780822381372

Mol, A. 2002. The body multiple: ontology in medical practice. Durham: Duke University Press. DOI: https:// doi.org/10.1215/9780822384151

Nicely, MV. 2018. Butoh's subversive somatics. Journal Of Dance \& Somatic Practices, 10(1): 111-126. DOI: https://doi.org/10.1386/jdsp.10.1.111_1

Nolas, S-M and Varvantakis, C. 2018. Entanglements that matter. Entanglements: experiments in multimodal ethnography, 1(1): 1-4.

Petitmengin, C, van Beek, M, Bitbol, M, Nissou, J and Roepstorff, A. 2019. Studying the experience of meditation through micro-phenomenology. Current opinion in psychology, 28: 54-59. DOI: https://doi. org/10.1016/j.copsyc.2018.10.009

Pink, S. 2011. Multimodality, multisensoriality and ethnographic knowing: social semiotics and the phenomenology of perception. Qualitative Research, 11(3): 261-276. DOI: https://doi. org/10.1177/1468794111399835

Sheets-Johnstone, M. 1981. Thinking in movement. The Journal of Aesthetics and Art Criticism, 39(4): 399-407. DOI: https://doi.org/10.2307/430239

Sheets-Johnstone, M. 1999. The primacy of movement. Amsterdam; Philadelphia: John Benjamins. DOI: https://doi.org/10.1075/aicr.14

Spinoza, BD and Curley, EM. 1994. A Spinoza reader: the Ethics and other works. Princeton; Chichester: Princeton University Press. DOI: https://doi.org/10.1515/9780691209289

Suhr, C and Willerslev, R. 2013. Transcultural montage. New York: Berghahn Books.

Szynkarczuk, P. 2015. Intercorporeality - Merleau-Ponty's ontology of flesh and butoh dance practice. Doctoral thesis, Goldsmiths, University of London.

Taussig, M. 2009. What do drawings want? Culture, Theory and Critique, 50(2-3): 263-274. DOI: https:// doi.org/10.1080/14735780903240299 
Taylor, JS. 2005. Surfacing the body interior. Annual Review of Anthropology, 34: 741. DOI: https://doi. org/10.1146/annurev.anthro.33.070203.144004

Willerslev, R. 2007. Soul hunters: hunting, animism, and personhood among the Siberian Yukaghirs. Berkley, Los Angeles and London: University of California Press. DOI: https://doi.org/10.1525/9780520941007

Young, D. 2005. The smell of green-ness: cultural synaesthesia in the Western Desert (Australia). In: Bendix, R and Brenneis, D The Senses, Etnofoor, 18: 61-77.

\section{INTERNET SOURCES}

Sankai Juku image, file name: Sankai Juku2.jpg, attribution: CC 2.0 Generic (CC BY 2.0), source: https:// commons.wikimedia.org/wiki/File:Sankai_Juku2.jpg.

Semimaru (SANKAI JUKU) Workshop Digest (1 August 2020). 蟬丸（山海塾）ワークショップダイジェスト https://www.youtube.com/watch?v=RF_P-B65mvs (first accessed September 2020; last accessed July 2021).

TO CITE THIS ARTICLE: Esposito, P and Dziala, D. 2021. Becoming a Caterpillar: A Multimodal Perspective on Metamorphosis in Butoh Dance. Journal of Embodied Research, 4(1): 4 (25:04). DOI: https://doi.org/10.16995/jer.18

Submitted: 28 February 2019 Accepted: 24 July 2021

Published: 16 September 2021

COPYRIGHT:

(c) 2021 The Author(s). This is an open-access article distributed under the terms of the Attribution-NonCommercialNoDerivatives 4.0 International License (CC BY-NC-ND 4.0), which permits unrestricted use, distribution, and reproduction in any medium, provided the original author and source are credited. See https:// creativecommons.org/licenses/ by-nc-nd/4.0/.

Journal of Embodied Research is a peer-reviewed open access journal published by Open Library of Humanities. 